\title{
Eocene and not Cretaceous origin of spider wasps: Fossil evidence from amber
}

Juanita Rodriguez, Cecilia Waichert, Carol D. Von Dohlen, George Poinar Jr, and James P. Pitts Acta Palaeontologica Polonica 61 (1), 2016: 89-96 doi:http://dx.doi.org/10.4202/app.00073.2014

Spider wasps had long been proposed to originate in the mid-Cretaceous based on the Burmese amber fossil Bryopompilus interfector Engel and Grimaldi, 2006. We performed a morphological examination of this fossil and determined it does not belong to Pompilidae or any other described hymenopteran family. Instead, we place it in the new family Bryopompilidae. The oldest verifiable member of the Pompilidae is from Baltic amber, which suggests the family probably originated in the Eocene, not in the mid-Cretaceous as previously proposed. The origin of spider wasps appears to be correlated with an increase in spider familial diversity in the Cenozoic. We also we add two genera to the extinct pompilid fauna: Tainopompilus gen. nov., and Paleogenia gen. nov., and describe three new species of fossil spider wasps: Anoplius planeta sp. nov., from Dominican amber (Burdigalian to Langhian); Paleogenia wahisi sp. nov., from Baltic amber (Lutetian to Priabonian); and Tainopompilus argentum sp. nov, from Dominican amber (Chattian to Langhian).

Key words: Hymenoptera, Pompilidae, solitary wasps, amber, Eocene, Dominican Republic, Baltic sea, Russia.

Juanita Rodriguez [juanitarodrigueza@gmail.com], Cecilia Waichert [cwaichert@gmail.com ], Carol D. von Dohlen [Carol.vonDohlen@usu.edu], and James P. Pitts [james.pitts@usu.edu ], Utah State University, Department of Biology, 5305 Old Main Hill, Logan, UT 84322-5305, USA. George Poinar Jr. [poinarg@science.oregonstate.edu], Oregon State University, Department of Zoology, 3029 Cordley Hall, Corvallis, OR 97331, USA.

This is an open-access article distributed under the terms of the Creative Commons Attribution License (for details please see creativecommons.org), which permits unrestricted use, distribution, and reproduction in any medium, provided the original author and source are credited. 
FoF Full text $(507.3 \mathrm{kB})$ 